\title{
Those Who Can Become "Foreign Koreans" Globalisation, Transnational Marriages and Shifting Nationalist Discourse in South Korea
}

\author{
Sohoon Lee ${ }^{1}$
}

This paper postulates that South Korea's multicultural rhetoric is written in neoliberal terms and is part of the state's new nationbuilding discourse. Following the Asian Financial Crisis of 1997, South Korean nationalism has been reshaped to impose neoliberal ideals on its citizens. Similarly, foreign populations such as marriage migrants have been objectified into specific roles needed in the national economy. The government has used their economic role as means to justify their presence in society while at the same time limiting their political and civil rights. The current paradigm deliberately marks the "foreignness" of biracial populations to emphasise their market value - and therefore their justified stay-in Korea. This paper starts with a theoretical discussion for South Korean state nationalism and reviews globalisation-inspired changes in light of nationalist discourse. Then the paper draws on field notes, participant observation data, interviews, documentary analysis and case study to review Korea's "multicultural" policies and argue that the selective acceptance of migrants and their social hierarchy are codified in legal structure. [Article copies available for a fee from The Transformative Studies Institute. E-mail address: journal@transformativestudies.org Website: http://www.transformativestudies.org (C2012 by The Transformative Studies Institute. All rights reserved.]

KEYWORDS: Nationalism, Neoliberal Welfarism, Neo-Pluralism, Marriage Migration.

\footnotetext{
${ }^{1}$ Sohoon Lee has completed her Master's degree in political science at the University of Toronto. She has since worked at various rights groups in Thailand and South Korea including Asia Forum for Human Rights and Development (FORUM-ASIA) and Migrants' Trade Union. She currently studies Human Rights and Democratisation at the University of Sydney. Address correspondence to: Ms. Sohoon Lee, University of Sydney, SSPS, RC Mills Room 140, Sydney, NSW, 2006, Australia; tel: +614 2682 2823; fax: +612 9036 9380; e-mail: sohoon.m.lee@gmail.com.
} 